JERZY JANCZEWSKI

Akademia Humanistyczno-Ekonomiczna w Łodzi, Polska - University of Humanities and Economics in Lodz, Poland

\title{
Usługi motoryzacyjne w perspektywie elektromobilności i Internetu rzeczy
}

\section{Automotive Services in the Context of Electromobility and Internet of Things}

Streszczenie: Konieczność dbania o naturalne środowisko i coraz bardziej restrykcyjne normy emisji spalin powodują, że nieuniknione jest zastępowanie napędów spalinowych napędami elektrycznymi. Samochód nadal będzie stanowił główny środek zarówno transportu indywidualnego, jak i zbiorowego. Brakuje przesłanek wskazujących na to, że w najbliższej przyszłości może być wyeliminowany z użycia i zastąpiony przez inne środki, a jego eksploatacja, tak jak w wypadku każdej innej maszyny, będzie wymagała udziału zaplecza usługowego. Celem niniejszego artykułu jest wskazanie na zmiany w usługach motoryzacyjnych, szczególnie w sektorze serwisowania i napraw samochodów, wynikające ze zbliżającej się elektromobilności, autonomizacji pojazdów i Internetu rzeczy. Aby zrealizować ten cel, scharakteryzowano koncepcję i założenia elektromobilności w Polsce oraz determinanty rozwoju tradycyjnych i elektrycznych pojazdów samochodowych, omówiono też zagadnienie Internetu rzeczy i autonomizacji pojazdów oraz przedstawiono przykładowe rozwiązania dla motoryzacji w przyszłości. $\mathrm{W}$ podsumowaniu zwrócono uwagę na czynniki stanowiące rezultat tych zmian, mające zasadniczy wpływ na sektor serwisowania, takie jak: pozyskiwanie nowej wiedzy i umiejętność korzystania z rosnącej liczby informacji, uzupełnianie i stałe aktualizowanie nowoczesnego sprzęt serwisowego, zmiany w procesach obsługi i naprawy pojazdów, diagnozowanie samochodów i aktualizowanie ich oprogramowania na odległość.

\begin{abstract}
The necessity of caring for the natural environment and the increasingly restrictive emission standards cause that substitution of combustion drives with electric drives is inevitable. The car will continue to be the main means of both individual and collective transport. There are no indications that in the near future it may be eliminated from use and replaced by other means and its operation will still require the participation of service facilities just like any other machine. The aim of the article is to point to changes in automotive services, especially in the car service and repair sector, resulting from the approaching electromobility, autonomy of vehicles and the Internet of Things. Implementing the goal of the study, the concept and assumptions of electromobility in Poland, the determinants of the development of traditional and electric vehicles were characterised, the issue of the Internet of Things and the autonomy of vehicles was discussed, and examples of automotive solutions for the future were presented. The summary draws attention to the factors resulting from these changes and those that have a major
\end{abstract}


impact on the services sector, such as: acquiring new knowledge and the ability to use the growing number of information, supplementing and constantly updating modern service equipment, changes in the processes of servicing and repairing vehicles, diagnosing cars and remotely updating their software.

Słowa kluczowe: autonomizacja; elektromobilność; Internet rzeczy; warsztat samochodowy

Keywords: autonomisation; electromobility; car service; Internet of Things

Otrzymano: 17 listopada 2017

Received: 17 November 2017

Zaakceptowano: 28 maja 2018

Accepted: 28 May 2018

\section{Sugerowana cytacja/Suggested citation:}

Janczewski, J. (2018). Usługi motoryzacyjne w perspektywie elektromobilności i Internetu rzeczy. Przedsiębiorczość - Edukacja [Entrepreneurship - Education], 14, 205-220. DOI: $10.24917 / 20833296.14 .15$

\section{Wstęp}

Motoryzacja dla wielu państw ma duże znaczenie gospodarcze. W Polsce jest jednym z największych sektorów przemysłu i odpowiada za 9,7\% wartości produkcji sprzedanej w tej części gospodarki (Branża motoryzacyjna Raport, 2015: 160). W Stanach Zjednoczonych w roku 2014 cała branża ${ }^{1}$ wygenerowała przychody w wysokości 2 bln dolarów, czyli 11,5\% łącznego PKB (Corwin, Vitale, Kelly, Cathles, 2015: 3).

Firma konsultingowa Deloitte w raporcie zatytułowanym Przyszłość transportu. W jaki sposób techniki transportowe i trendy społeczne tworza nowe ekosystemy gospodarcze do najistotniejszych przesłanek wskazujących na nadejście ewolucji w szeroko rozumianym sektorze motoryzacyjnym zaliczyła, oprócz rozwoju nowoczesnych technologii napędowych i postępu w dziedzinie wytrzymałych i lekkich materiałów konstrukcyjnych, rozwój techniki komputerowej oraz technologii informatycznych, a także pomyślne wyniki prac nad wykorzystaniem w transporcie pojazdów autonomicznych (Corwin, Vitale, Kelly, Cathles, 2015: 10).

Trend proekologiczny, a także - w dalszej perspektywie - możliwość zasilania pojazdów za darmo przez energię słoneczną powinny znacznie przyspieszyć, choćby częściowe, wyeliminowanie $z$ użytkowania tradycyjnego silnika spalinowego ${ }^{2}$. Samochód przez to będzie przyjazny środowisku, mechanicznie mniej skomplikowany, prostszy w budowie i wymagający mniej czynności obsługowo-naprawczych. Obecnie już wszystkie liczące się na rynku firmy motoryzacyjne oferują swoim klientom samochody z silnikiem elektrycznym. Pojazdy te w niedalekiej przyszłości będą dominować w transporcie, szczególnie na krótszych odcinkach, np. w miastach, ale i także w dalszych podróżach. Wskazują na to osiągnięcia takich firm, jak Tesla lub Solaris. Tej pierwszej - w dziedzinie żywotności

\footnotetext{
${ }^{1}$ Producenci samochodów, dostawcy, dealerzy, firmy oferujące usługi finansowe, spółki naftowe, sprzedawcy detaliczni paliw, dostawcy części zamiennych, ubezpieczyciele, właściciele państwowych i prywatnych parkingów, a także: wpływy z podatków, opłat za korzystanie z dróg i autostrad, z tytułu egzekwowania przestrzegania przepisów ruchu drogowego, usług medycznych i innych.

${ }^{2}$ Tradycyjny silnik spalinowy trudno jest całkowicie wyeliminować z zastosowania w transporcie, zwłaszcza w środkach transportu używanych do pokonywania dystansów powyżej $1000 \mathrm{~km}$.
} 
zasobników energii (baterii), zasięgu i malejącej ceny za pojazd elektryczny, a drugiej w dziedzinie rozwoju i produkcji autobusów elektrycznych.

Oprócz rozpowszechnianego napędu elektrycznego, stanowiącego podstawę koncepcji elektromobilności, współczesne pojazdy samochodowe wykorzystują coraz więcej funkcji informatycznych i multimedialnych. Duże znaczenie dla przyszłego samochodu, w tym i dla branży usług motoryzacyjnych, ma koncepcja Internetu rzeczy oraz osiągnięcia w obszarze autonomizacji pojazdów.

Celem niniejszego artykułu jest wskazanie na zmiany w usługach motoryzacyjnych, szczególnie w sektorze serwisowania i napraw samochodów, wynikające ze zbliżającej się elektromobilności, autonomizacji pojazdów i Internetu rzeczy.

\section{Koncepcja i założenia elektromobilności w Polsce}

Elektromobilność to koncepcja zakładająca wykorzystanie ekologicznych, bezemisyjnych pojazdów elektrycznych zamiast pojazdów zasilanych paliwami kopalnymi. Może być ona rozpatrywana w wymiarze miasta, regionu, kraju, kontynentu lub znacznie szerzej. Pojazdy elektryczne wymagają zastosowania nowych technologii, takich jak unowocześnione zasobniki energii elektrycznej (akumulatory), elektroniczne układy zasilania, aerodynamiczna budowa, lekkie materiały i integracja z siecią energetyczną. Samochody elektryczne potrzebują stacji ładujących, inteligentnych sieci cyfrowych i systemów sterowania siecią umożliwiających płynne podróżowanie przez różne kraje, popularyzacji wśród kierowców, integracji z pozostałymi środkami transportu oraz zaawansowanych rozwiązań logistycznych.

Rozwój pojazdów o napędzie elektrycznym jest dużym impulsem dla postępu zarówno w przemyśle motoryzacyjnym, jak i w wielu innych przemysłach pracujących na jego rzecz. Jednocześnie technologia pojazdów z napędem elektrycznym w dużym stopniu przyczynia się do sprostania niektórym wyzwaniom, takim jak globalne ocieplenie klimatu, zależność od importu ropy naftowej i jej pochodnych, lokalne zanieczyszczenia powietrza oraz stabilizacja krajowych sieci elektroenergetycznych przez gromadzenie energii elektrycznej w akumulatorach samochodowych (Emilewicz, 2017).

W Polsce elektromobilność nabiera szczególnego znaczenia, a jej rozszerzenie stanowi jeden ze strategicznych projektów zapisanych w przyjętej przez rząd Strategii na rzecz Odpowiedzialnego Rozwoju. Strategia ta zakłada produkcję pojazdów o napędzie elektrycznym oraz budowę infrastruktury niezbędnej dla tego typu pojazdów, co m.in. pozwoli na stworzenie ekologicznego transportu publicznego w polskich miastach (projekty: „e-Bus” i „e-Car”; Strateg ia na rzecz Odpowiedzialnego Rozwoju..., 2017).

Cele dla rozwoju elektromobilności w Polsce określono w Planie rozwoju elektromobilności przygotowanym przez Ministerstwo Energii. Plan ten proponuje działania, które doprowadzą do upowszechnienia infrastruktury ładowania i pojazdów elektrycznych na polskich drogach, rozwoju przemysłu elektromobilności oraz stabilizacji sieci elektroenergetycznej.

Plan wyszczególnia trzy fazy rozwoju elektromobilności. Pierwsza faza to okres przygotowawczy, który potrwa do 2018 r. Najważniejszym jego elementem jest przyjęcie ustawy o elektromobilności, inicjacja badań naukowych i skoncentrowanie finansowania publicznego. Druga faza (2019-2020) przewiduje zbudowanie infrastruktury zasilania pojazdów elektrycznych w wybranych aglomeracjach miejskich i zintensyfikowanie zachęt 
do zakupu tych pojazdów. W tej fazie oczekiwana jest też komercjalizacja wyników badań z obszaru elektromobilności oraz wdrożenie nowych modeli biznesowych upowszechnienia pojazdów elektrycznych. Trzecia faza (2020-2025) zakłada stopniowe osiąganie dojrzałości przez rynki elektromobilności i wycofywanie przez rząd instrumentów wsparcia (Ministerstwo Energii, 2017; Zaręba, 2017).

W Polsce ważna rolę w rozwoju elektromobilności odgrywa Polski Fundusz Rozwoju, który kieruje realizacją programu „e-Bus”. Celem tego programu jest budowa systemu umożliwiającego powstanie rynku autobusów elektrycznych. Zamierzeniem jest stworzenie autobusu elektrycznego dostępnego cenowo, efektywnego w eksploatacji i dojrzałego technologicznie, składającego się w dużej mierze z polskich komponentów. Polskie firmy produkujące autobusy elektryczne i cieszące się dobrą opinią użytkowników w naszym kraju, Europie i na świecie mogą stać się liderami w tym obszarze. Według danych z marca 2017 r. 49 polskich miast zadeklarowało wolę wdrażania elektromobilności i zakupu do 2020 r. 819 autobusów elektrycznych, przy czym w trakcie zakupu było już 321 autobusów.

W ramach programu rozwijania elektromobilności uruchamianych jest szereg programów konkursowych kierowanych do środowiska naukowego oraz do firm z sektora elektromobilności (szerzej w: Nawrat, 2017; Benysek, 2017; Program priorytetowy..., 2017). Dodatkowo niektóre miasta ze wschodniej Polski otrzymały wsparcie w realizacji inwestycji rozwijających ekologiczną komunikację miejską (Hrymniak, 2017).

Ważną częścią Planu rozwoju elektromobilności w Polsce jest stworzenie spółki ElectroMobility Poland SA, którą w 2016 r. założyły cztery polskie koncerny energetyczne - PGE Polska Grupa Energetyczna SA, Energa SA, Enea SA oraz Tauron Polska Energia SA. Celem ElectroMobility Poland SA jest przygotowanie warunków dla rozwoju systemu elektromobilności w Polsce. Zamierzeniem spółki jest stworzenie nowoczesnego samochodu miejskiego wpisującego się w aktualne trendy motoryzacyjnego rozwoju pojazdów elektrycznych. W ramach inicjatywy „e-Car” spółka zorganizowała konkurs, którego celem było wyłonienie pięciu koncepcji elektrycznego pojazdu przyszłości stanowiących podstawę do produkcji prototypów polskiego samochodu elektrycznego. Kryteriami wyboru projektów była ich wartość artystyczna, możliwość zbudowania i produkcji, ergonomia, efektywność energetyczna, innowacyjność i bezpieczeństwo (więcej w: http:// konkurs.emobilitypoland.pl/\#galeria).

W dalszych planach spółki jest przeprowadzenie konkursu na budowę prototypów polskiego samochodu elektrycznego. Konkurs będzie skierowany do producentów pojazdów lub komponentów z branży samochodowej, a jego cel to uzyskanie gotowych prototypów. Spółka ElectroMobility ogłosiła już wstępne założenia konkursu na prototyp. Obecnie (listopad 2017) konsultuje je z potencjalnymi uczestnikami konkursu.

Wsparciem dla polskiego przemysłu bezemisyjnych pojazdów elektrycznych jest planowana ustawa o elektromobilności i paliwach alternatywnych wprowadzająca wiele korzystnych rozwiązań dla kierowców, którzy zdecydują się na zakup samochodu elektrycznego. Będą to m.in. korzyści finansowe, takie jak obniżona akcyza i zwiększone odpisy amortyzacyjne, a także np. możliwość poruszania się samochodów elektrycznych po buspasach czy specjalne miejsca parkingowe w centrach miast oraz możliwość korzystania z darmowych parkingów. Zakłada się, że pakiet korzyści, który wprowadzi ustawa o elektromobilności, pomoże rozwinąć rynek pojazdów elektrycznych ( $W$ listopadzie..., 2017). 
Determinanty rozwoju tradycyjnych i elektrycznych pojazdów samochodowych

Do najważniejszych wyznaczników rozwoju tradycyjnych pojazdów samochodowych należą: administracyjne ograniczanie emisji spalin, oszczędność paliwa, zastosowanie paliw zamiennych (alternatywnych), skojarzenie z silnikiem elektrycznym (hybryda), a także bezobsługowość i niezawodność. W przypadku samochodów wyłącznie z napędem elektrycznym są to: zasięg pojazdu, pojemność zasobnika energii (akumulatora), związany z tym koszt jego wyprodukowania i stosunek mocy do jego masy, ograniczona liczba punktów uzupełniania energii, czas tego uzupełniania, późniejsze wykorzystanie akumulatora, a na koniec jego recykling i powrotne wprowadzenie do obiegu. Istotnymi ograniczeniami dla rozwoju pojazdów elektrycznych są ich relatywnie wysoka cena w porównaniu z konwencjonalnym odpowiednikiem oraz przyzwyczajenia użytkowników samochodów.

Powszechnie stosowany silnik spalinowy w porównaniu z silnikiem elektrycznym jest o wiele mniej efektywnym źródłem napędu. Pomimo tego jest on ciągle unowocześniany i stale przystosowywany do spełnienia coraz bardziej rygorystycznych wymagań dotyczących ograniczenia emisji spalin. Ulepszenia polegają m.in. na optymalizacji technologii ograniczania tarcia, w tym nowych powłok powierzchniowych, technik odprowadzania ciepła i zaawansowanych smarów oraz na inteligentnym zarządzaniu energią, optymalizacji układu spalania i elementów układu doprowadzania powietrza oraz zastosowaniu w pojazdach przenośnych systemów pomiaru emisji (POWERFUL Report Summary, 2015). Dodatkowo stale są prowadzone prace nad sztucznymi paliwami (Kościelniak, 2011), np. firma Bosch proponuje dla silników spalinowych nowe paliwo syntetyczne, tzw. eFuels, które po spaleniu całkowicie redukuje emisję do atmosfery dwutlenku węgla (Brzeziński, 2017). Podobne prace prowadzi firma Audi (Audi systematycznie..., 2017).

Bezpośredni wpływ na trendy w konstrukcji silników spalinowych mają administracyjne ograniczenia emisji spalin. Konieczność spełnienia tych wymagań wyzwala ciąg działań zarówno w obszarze nowych konstrukcji, jak i technologii oraz procesów ${ }^{3}$. Takim przykładem może być idea downsizingu zakładająca zbudowanie silnika spalinowego zużywającego mało paliwa, osiągającego dużą moc, emitującego mało szkodliwych substancji i odznaczającego się wysoką trwałością. Założenia te, choć są oczywiste, to również są sobie przeciwstawne, gdyż nie można bez końca zmniejszać silników, utrzymując jednocześnie ich moc, odpowiedni moment obrotowy, niskie zużycie paliwa oraz trwałość. Jakiś czas temu osiągnięto pułap downsizingu, poniżej którego silnik spalinowy jest już nieekonomiczny, drogi w produkcji, awaryjny i nietrwały. Z drugiej strony współczesny samochód staje się coraz większy, nierzadko cięższy, stąd na rynku od pewnego czasu obserwuje się zapowiedź trendu będącego całkowitym zaprzeczeniem idei downsizingu, czyli tzw. upsizing gdzie coraz większe stają się zarówno same silniki, jak i ich pojemność (Śnigurski, 2017). Zatem obecnie znaczące obniżenie zawartości szkodliwych substancji

\footnotetext{
${ }^{3}$ Trudności w spełnieniu wymagań ostatniej normy sprawiły, że niektóre koncerny podjęły działania niezgodne z prawem, czego przykładem jest afera Diselgate. Zdaniem SDCM, w cieniu tej afery dyskusje dotyczące przyszłych planów emisji dwutlenku węgla są bardzo emocjonalne. Pojazdy przedstawiane są w sposób zero-jedynkowy, te spalinowe są „złe” niezależnie od norm, które spełniają, z kolei pojazdy elektryczne są „dobre”, niezależnie od skutków procesu produkcji energii elektrycznej i akumulatorów (Ta decyzja..., 2017).
} 
w spalinach (zarówno silników benzynowych, jak i wysokoprężnych) możliwe jest tylko wówczas, gdy silniki te cofnie się częściowo w rozwoju, czyli gdy będą mniej wydajne będą zużywać więcej paliwa i emitować więcej dwutlenku węgla. Otwarte zatem pozostaje pytanie, w jaki sposób producentom tradycyjnych pojazdów samochodowych uda się spełnić kolejne obostrzenia norm emisji spalin zapowiadane po $2020 \mathrm{r}$.

Interesującym rozwiązaniem jest skojarzenie w samochodach napędu spalinowego z napędem elektrycznym, popularnie zwane rozwiązaniem hybrydowym. Rozwiązanie to, podobnie jak stosowanie paliw alternatywnych, traktowane jest jako przejściowe w dążeniu do całkowitego wyeliminowania silnika spalinowego i zastąpienia go silnikiem elektrycznym. Obecnie napęd ten cieszy się dużą popularnością wśród użytkowników, czego dowodem jest stale rosnąca sprzedaż samochodów hybrydowych (Główny Urząd Statystyczny, 2017).

Samochód hybrydowy korzysta z dwóch sposobów napędu i częściowo godzi ze sobą dwa skrajne wymagania - to pierwsze, związane z zerową emisyjnością pojazdu w codziennym użytkowaniu (póki co na krótkich dystansach) i to drugie, dotyczące pokonywania długich odcinków. Samochody hybrydowe są znacznie oszczędniejsze od samochodów z napędem tradycyjnym, gdyż dostosowują właściwe źródło napędu do aktualnych wymagań kierowcy. W czasie jazdy miejskiej, przy dużej liczbie różnych manewrów oraz stosunkowo niewielkich prędkościach i dystansach, korzystniejszy jest napęd elektryczny. Natomiast podczas pokonywania dłuższych odcinków z wysoką jednostajną prędkością, np. dróg ekspresowych czy autostrad, lepszą ekonomiką cechuje się silnik spalinowy. Zastosowanie zaawansowanych systemów sterujących dodatkowo wspomaga dopasowanie udziału w napędzie jednostki elektrycznej i spalinowej do aktualnego zapotrzebowania energii. Wszystko to przyczynia się do uzyskania oszczędności paliwa i tym samym mniejszej emisji spalin.

Oprócz zalet pojazdy hybrydowe mają też i wady. Główną z nich jest relatywnie wyższa cena. Do budowy samochodu hybrydowego potrzebne są droższe komponenty, a akumulatory gromadzące energię zajmują dużo miejsca, co znacznie ogranicza przestrzeń ładunkową pojazdu i jednocześnie zwiększa jego masę. Proces ładowania z gniazdka (plug in) trwa od kilku do kilkunastu godzin. Problem stanowią także niskie temperatury, przy których akumulator traci ok. 50\% pojemności, oraz żywotność samego akumulatora i późniejszy jego recykling. Należy również zaznaczyć, że zarówno produkcja akumulatorów, jak i w rezultacie ich recykling znacznie obciążają środowisko naturalne.

Pojazdy w pełni elektryczne, tzw. zero emisyjne, wykorzystują wyłącznie energię elektryczną. Silniki elektryczne nie są wspomagane spalinowymi ani do napędu pojazdu, ani do ładowania akumulatorów i wydają się być prawie idealnym rozwiązaniem, gdyż mają prostszą budowę w porównaniu z sinikami spalinowym, a zatem i niższy koszt produkcji oraz eksploatacji. Elektryczne napędy są łatwe w sterowaniu, mają duży moment obrotowy, dostarczają wysokich przyspieszeń i podczas hamowania korzystają z systemu rekuperacji energii. Podobnie jak w przypadku pojazdów hybrydowych główną determinantą rozwoju napędów elektrycznych jest zasobnik energii, jego koszt i związany z tym zasięg samochodu. Koncerny samochodowe oferują tutaj różne rozwiązania, np. Renault proponuje dzierżawę baterii (Maj, 2013). Tesla osiągnęła już rekordowy zasięg 1000 km (Kulik, 2015), a akumulator grafenowy ma krótki czas ładowania (Baterie grafenowe, 2016). Stąd rzeczywisty zasięg stale się zwiększa, lecz w porównaniu z silnikami konwencjonalnymi nadal jest niezadawalający. 
Współczesny samochód oprócz obowiązkowego oświetlenia ma też szereg innych udogodnień wymagających zasilania elektrycznego, takich jak klimatyzacja i ogrzewanie, systemy multimedialne i wiele innych. W niedalekiej perspektywie planuje się wyprodukowanie autonomicznego samochodu elektrycznego, którego systemy miałyby jeszcze większą potrzebę konsumpcji energii. Problemem staje się użytkowanie samochodu elektrycznego w strefach o chłodnym, a także umiarkowanym klimacie, gdy pojemność akumulatora maleje wraz ze spadkiem temperatury otoczenia. Do tego dochodzą niedogodności związane z szybkim ładowaniem akumulatorów (tankowanie paliwem tradycyjnym trwa zaledwie chwilę), brakiem wystarczającej liczby punktów ładowań, standaryzacją i wiele innych. W końcowym rezultacie rozważań nad wyborem przez użytkownika samochodu elektrycznego czy tradycyjnego wciąż przeważa wysoka cena zakupu tego pierwszego i konieczność wymiany baterii co 8-10 lat, co wiąże się z wysokim kosztem, a w przyszłości może mieć duży wpływ na ograniczenie rynku wtórnego używanymi samochodami. Być może pewnym rozwiązaniem będzie późniejsze wykorzystanie w gospodarstwach domowych używanych akumulatorów jako domowych zasobników energii (Dach solarny..., 2016) pod warunkiem, że rozpowszechni się idea energetyki rozproszonej. Stale aktualny jest problem recyklingu pozostałości całkowicie zużytych akumulatorów, a wcześniej ich nieekologicznej i energochłonnej produkcji (szerzej w: Szokujący raport..., 2017). Końcowym problemem, który jest niezwykle istotny, a o którym jeszcze się mało mówi, jest pochodzenie energii elektrycznej - jeśli nadal będzie ono z paliw naturalnych, a nie ze źródeł odnawialnych, to w globalnym rozrachunku korzyści będą polegały wyłącznie na ograniczeniu nadmiernego rozproszenia sprawców emisji spalin do atmosfery, co jest istotne w dużych aglomeracjach i metropoliach lub kompleksach turystyczno-rekreacyjnych. W realnej perspektywie pozostaje więc jeszcze możliwość zastosowania ogniwa paliwowego i produkcja energii elektrycznej bezpośrednio w samochodzie. Takie rozwiązanie eliminuje wymienione ograniczenia związane z zasięgiem i produkcją zasobników energii elektrycznej, ale przysparza nowych problemów do rozwiązania, takich jak produkcja wodoru, jego bezpieczna dystrybucja i magazynowanie (szerzej w: Mirai..., 2016).

Rozwój sektora pojazdów elektrycznych jest ograniczany również przez kwestie mentalne, przede wszystkim obawę przed zmianami i niekiedy niewłaściwe pojmowanie rezultatów innowacji. Tradycyjny przemysł paliwowy nie tylko dostarcza licznych stanowisk pracy, lecz także zapewnia wysokie wpływy do budżetów państw, stanowi też wpływowe lobby. Popularyzacja pojazdów elektrycznych pociąga za sobą konieczność zmiany sposobu życia i postrzegania samochodu. Zmiana wynikająca z elektryfikacji transportu może być dla niektórych osób korzystna (elektryczne autobusy) pod warunkiem, że nie zdrożeją bilety komunikacji miejskiej. Wymagać też będzie więcej elastyczności, cierpliwości i zrozumienia (elektryczne samochody), gdyż przyzwyczajenia ludzi są ich drugą naturą.

Wprawdzie wsparcie dla modeli biznesowych, w których produkuje się i sprzedaje samochody elektryczne, jest już oczywiste, jednak póki co, to producenci samochodów spalinowych i części do tych samochodów napędzają gospodarkę (Raport..., 2017).

Polsce będzie bardzo trudno samodzielnie stworzyć nowe trendy na rynku elektromobilności, ponieważ jest to rynek całkowicie zdominowany przez zagraniczne koncerny określające kierunki rozwoju i tym samym narzucające swoje warunki. Nasz kraj może jednak spróbować otworzyć kolejne nisze typu mały, miejski pojazd elektryczny, tak jak 
zamierza to uczynić spółka ElectroMobility (W listopadzie..., 2017). Warto tutaj skorzystać z doświadczeń zachodnich sąsiadów. Przykładowo w Norwegii samochody elektryczne stanowią już większość sprzedawanych nowych pojazdów. Holandia ogłosiła, że do 2025 r. zrezygnuje z rejestracji nowych samochodów spalinowych. Podobnie, choć do roku 2040, zamierza to uczynić Wielka Brytania.

\section{Internet rzeczy i autonomizacja pojazdów}

Postęp i rozwój zastosowań Internetu sprawiają, że staje się on powoli trzecią przestrzenią życiową dla człowieka po domu i pracy. Szacuje się, że do 2022 r. światowy rynek usług mobilnych wykorzystujących Internet rzeczy będzie wzrastać o blisko $25 \%$ rocznie.

Elektryfikacja, integracja z Internetem oraz automatyzacja - to trzy ważne obszary, które w przyszłości ukształtują bezwypadkową, bezemisyjną i bezstresową mobilność (Dener w: Piszcz, 2017). W przeciągu kilku lat samochody staną się integralną częścią Internetu rzeczy. Będzie zatem możliwa zaawansowana łączność sieciowa wewnątrz i na zewnątrz pojazdu, np. komunikacja na liniach pojazd-użytkownik, pojazd-pojazd, pojazd-infrastruktura, pojazd-inteligentny dom czy pojazd-warsztat naprawczy.

Badanie Connected Car Effect 2025 wykonane przez firmę Bosch oraz firmę konsultingową Prognos pokazuje, jak w perspektywie niespełna 10 lat powinno zmienić się prowadzenie samochodów na skutek podłączania ich do Internetu. Firmy te przewidują, że do roku 2025 większość samochodów będzie podłączona do sieci i wyposażona w elektroniczne systemy podnoszące bezpieczeństwo i komfort jazdy, a w co drugim samochodzie popularne obecnie smartfony będą zintegrowane $\mathrm{z}$ systemem infotainment (łączącymi rozrywkę $\mathrm{z}$ informacją). Na potrzeby tego badania firmy przeprowadziły obliczenia dla USA, Chin i Niemiec. Z uzyskanych danych wynika, że podłączenie pojazdów do Internetu przełoży się na roczne zmniejszenie liczby wypadków z udziałem rannych o ponad 260 tys., mniejszą o 350 tys. liczbę osób rannych w wypadkach drogowych, szybszą pomoc i - tym samym uratowanie - 11 tys. osób dzięki systemom wspomagającym, zmniejszenie strat materialnych i kosztów szkód o 4,3 mld euro, zmniejszenie emisji dwutlenku węgla o prawie 400 tys. ton, zaoszczędzenie około $70 \mathrm{mln}$ godzin jazdy i uzyskanie dla kierowców po 31 godzin wolnego czasu, który będą mogli przeznaczyć na inne zajęcia niekoniecznie związane z kierowaniem pojazdem (Connected Car Effect 2025, 2017).

Szacuje się, że do roku 2022 w 75\% nowych samochodów dostępny będzie system rozpoznawania mowy funkcjonujący w chmurze. Zaawansowane systemy wyposażone w pokładowe mikrofony i kamery będą potrafiły interpretować ton głosu kierowcy i jego wyraz twarzy. W przyszłości system rozpoznawania gestów i monitorowania oczu kierowcy powinien nawet pozwolić odebrać połączenie telefoniczne przez skinięcie głową lub dostosowanie poziomu głośności systemu audio i zaprogramowanie nawigacji, np. przez spojrzenie kierowcy na cel podróży na mapie. Zautomatyzowanie jazdy sprawi, że kierowca zamiast kierować pojazdem będzie mógł się skupić na innych czynnościach, takich jak np. czytanie i pisanie wiadomości, słuchanie muzyki czy oglądanie filmów (Januszkiewicz, 2017b), a samochód ze środka transportu przekształci się w osobistego asystenta kierowcy. Przykłady niektórych innowacyjnych rozwiązań dla motoryzacji przyszłości pokazano w tabeli 1 .

Obecnie coraz więcej pojazdów jest połączonych siecią z Internetem i z innymi samochodami oraz otaczającą je infrastrukturą. Powszechne wykorzystanie przez samochody 
Tab. 1. Przykładowe rozwiązania dla motoryzacji przyszłości

\begin{tabular}{|c|c|}
\hline Przykładowe rozwiązanie & Charakterystyka rozwiązania \\
\hline $\begin{array}{l}\text { Rozpoznawanie kierowcy } \\
\text { (Monitoring Camera Driver) }\end{array}$ & $\begin{array}{l}\text { System rozpoznający twarz kierowcy i dopasowujący } \\
\text { ustawienia pojazdu do jego osobistych preferencji, } \\
\text { np. ustawienie siedzenia i lusterek, temperatury wnętrza } \\
\text { itd. }\end{array}$ \\
\hline Panel kontroli gestów & $\begin{array}{l}\text { System wykorzystujący czujniki ultradźwiękowe do } \\
\text { rejestrowania ruchu rąk kierowcy, wyposażony w ekran } \\
\text { z przyciskami wykorzystującymi technologię haptyczną }\end{array}$ \\
\hline $\begin{array}{l}\text { System monitorujący środowisko } \\
\text { wokół pojazdu (Mirror Car System) }\end{array}$ & $\begin{array}{l}\text { System oparty na kamerach i czujnikach, monitorujący } \\
\text { środowisko dookoła pojazdu i przekazujący informację } \\
\text { na ekrany wyświetlające przy przednich bocznych } \\
\text { słupkach nadwozia pojazdu }\end{array}$ \\
\hline $\begin{array}{l}\text { Doskonały (kluczyk) dostęp } \\
\text { do pojazdu (Perfectly Keyless) }\end{array}$ & $\begin{array}{l}\text { System dostępu do pojazdu z poziomu smartfona, } \\
\text { działający na zasadzie cyfrowego kluczyka. Umożliwia } \\
\text { automatyczne otwarcie pojazdu z odległości ok. } 2 \text { m, gdy } \\
\text { kierowca zbliży się do pojazdu, trzymając smartfon przy } \\
\text { sobie, oraz automatyczne uruchomienie silnika, gdy tylko } \\
\text { smartfon znajdzie się } \\
\text { we wnętrzu pojazdu }\end{array}$ \\
\hline $\begin{array}{l}\text { Lokalizator miejsca na parkingu } \\
\text { (Community-based parking) }\end{array}$ & $\begin{array}{l}\text { System, który powoduje, że pojazd lokalizuje miejsce } \\
\text { parkingowe. Przy omijaniu pojazdów na parkingu system } \\
\text { rejestruje, czy przestrzeń między nimi jest wystarczająca } \\
\text { do zaparkowania, a przy tym przekazuje tę informację } \\
\text { do miejskiej chmury, dzięki czemu inni uczestnicy ruchu } \\
\text { wiedzą, jaka jest sytuacja na danym parkingu w mieście }\end{array}$ \\
\hline $\begin{array}{l}\text { Automatyczne parkowanie } \\
\text { samochodu (Automated Valet } \\
\text { Parking) }\end{array}$ & $\begin{array}{l}\text { System automatycznego wyszukiwania miejsca na } \\
\text { parkingu i parkowania samochodu }\end{array}$ \\
\hline Home zone park pilot & $\begin{array}{l}\text { System autonomicznego parkowania pojazdu } \\
\text { w prywatnym garażu lub wyznaczonym podziemnym } \\
\text { parkingu. Zapamiętuje raz wykonany przez kierowcę } \\
\text { podczas próby manewr parkowania w garażu, aby potem } \\
\text { samodzielnie go powtarzać }\end{array}$ \\
\hline $\begin{array}{l}\text { System ostrzegający kierowcę } \\
\text { o jeździe pod prąd }\end{array}$ & $\begin{array}{l}\text { System oparty na chmurze, który rejestruje ruch } \\
\text { wszystkich pojazdów w okolicy. Jeżeli któryś z nich } \\
\text { porusza się pod prąd, natychmiast powiadamia o tym } \\
\text { innych kierowców } \\
\text { oraz kierowcę jadącego pod prąd }\end{array}$ \\
\hline
\end{tabular}

Źródło: opracowanie własne na podstawie: Januszkiewicz (2017b)

chmury może także dotyczyć aktualizacji oprogramowania samochodów ${ }^{4}$. Współczesne pojazdy samochodowe są wyposażone w aż 100 jednostek sterujących (małe samochody mają ich nawet od 30 do 50), które za pomocą oprogramowania sterują wieloma funkcjami w pojeździe. Oznacza to większe ryzyko pojawienia się niedoskonałości

\footnotetext{
${ }^{4}$ Aktualizowanie samochodu przez chmurę nie wymaga wizyt w warsztacie samochodowym. W $2015 \mathrm{r}$. w USA 15\% sytuacji, w których kierowcy musieli odwiedzić warsztat samochodowy, miało związek z błędami w oprogramowaniu. Dla porównania - 4 lata wcześniej liczba ta wynosiła zaledwie 5\% według danych National Highway National Association (NHTSA). Dla producentów samochodów i ich klientów takie wizyty w warsztatach to ogromne straty czasu i koszty. Aktualizacje online mogą znacznie zmniejszyć ten poziom (Januszkiewicz, 2017a).
} 
w oprogramowaniu, co może skutkować manipulowaniem danymi. W tym kontekście aktualizacje oprogramowania przez chmurę stanowią rozwiązanie pozwalające stale utrzymywać samochody w bieżącej fazie (up to date), a tym samym zapewniać większe bezpieczeństwo (Januszkiewicz, 2017a; Łukaszewicz, Giecewicz, 2017).

Wymienione przykłady stanowią dowód motoryzacyjnego trendu projektowania w pełni niezależnych (autonomicznych) pojazdów, które dzięki zastosowaniu Internetu rzeczy obejdą się bez kierowcy i będą samodzielnie reagować na różne sytuacje na drodze. Pojazdy te mają stanowić główny element zintegrowanej, połączonej z Internetem infrastruktury drogowej. O dynamice wzrostu ich liczby świadczy fakt, że o ile w $2014 \mathrm{r}$. w naszej części Europy udział połączonych z siecią pojazdów wynosił 13\%, o tyle - wg niektórych prognoz - w 2020 r. osiągnie on 95\% (Greenough, 2015). Ten kierunek rozwoju rynku samochodowego może zrewolucjonizować branżę motoryzacyjną bardziej niż pojazdy hybrydowe czy elektryczne.

Tak zwane autonomiczne samochody, pojazdy posiadające zdolność poruszania się po ulicy bez ingerencji człowieka, opracowywane i testowane są w takich państwach, jak Stany Zjednoczone, Japonia, Chiny, Wielka Brytania, Niemcy, Szwecja czy Holandia. Coraz częściej pojawiają się poglądy, że samochody niepotrzebujące kierowcy wkrótce staną się codziennością. Zapewne wcześniej dotyczyć to będzie komunikacji zbiorowej w miastach i transportu ładunków, gdzie stale do pracy brakuje kierowców, a dopiero później transportu indywidualnego.

Prace nad pojazdami autonomicznymi prowadzą nie tylko firmy motoryzacyjne, jak na przykład Ford, Toyota, ale też potentaci z branży technologicznej, internetowej czy logistycznej, np. Google i Amazon. Samochody autonomiczne są wyposażone w systemy precyzyjnie informujące je o lokalizacji w stosunku do innych pojazdów oraz o potencjalnym niebezpieczeństwie. Do zalet pojazdów autonomicznych należy m.in. zaliczyć: zmniejszenie w przyszłości liczby kolizji, zwiększenie przepustowości i zmniejszenie zatorów na drogach, odciążenie kierowcy od czynności związanych z prowadzeniem pojazdu, zniesienie wielu ograniczeń dotyczących osób mogących kierować samochodem, zmniejszenie problemu zajętych miejsc parkingowych i redukcję fizycznie istniejących znaków drogowych. Ryzyko i problemy, które za sobą niosą pojazdy autonomiczne, to brak odpowiedniej liczby dokładnych cyfrowych map do poprawnego pozycjonowania i niezależnego sterowania, brak konkretnych i niezawodnych rozwiązań w sytuacjach krytycznych, np. gdy przy skręcie pojazd autonomiczny nie poradzi sobie z zaśnieżoną jezdnią, a także problemy z poprawnym odczytaniem gestów kontroli drogowej. Ponadto system nie rozpoznaje małych zwierząt, wybojów na drodze czy otwartych, niezabezpieczonych studzienek kanalizacyjnych. Nie jest też jeszcze zaprojektowany odpowiedni algorytm rozwiązujący problem z lewoskrętem na ruchliwej drodze, a samochód nie potrafi przejechać przez parking (Owczarzak, 2015). Niemniej jednak firma Bosch zapowiada, że już wkrótce, bo w 2020 r. samochody wyposażone w jej technologię będą mogły poruszać się w sposób wysoce zautomatyzowany po autostradach (trzeci poziom autonomii $\mathrm{SAE}^{5}$ ), następnie $\mathrm{w}$ pełni automatycznie $\mathrm{w}$ miastach (czwarty poziom autonomii SAE), a na koniec - bez udziału kierowcy (piąty poziom autonomii SAE). W 2018 r. pierwszym krokiem w kierunku autonomicznej jazdy, zapowiadanym przez firmę Bosch, będzie

${ }^{5}$ Poziomy autonomii samochodów według standardu SAE J3016 w: Unia o inteligentnych samochodach (2016). 
automatyczne wyszukiwanie wolnego miejsca i parkowanie na parkingu Muzeum Mercedesa-Benza w Stuttgarcie.

\section{Elektromobilność i Internet rzeczy vs. usługi motoryzacyjne}

Domeną usług motoryzacyjnych są naprawa i obsługa pojazdów samochodowych, stanowiące nieodzowny element eksploatacji każdej maszyny. Samochody niezależnie od sposobu napędu i poziomu autonomizacji wymagają serwisowania. W zależności od technicznego zaawansowania pojazdu mogą zmieniać się częstotliwość i zakres jego obsługi lub naprawy oraz udział w tych procesach czynnika ludzkiego. Wbrew obiegowym poglądom samochody hybrydowe i elektryczne nie są mechanicznie i konstrukcyjnie zbyt skomplikowane i awaryjne. Dowodzą tego wydłużone terminy gwarancji udzielane przez producentów (np. na zespoły samochodu 5 lat, akumulatory 8-10 lat). Serwisowanie samochodu hybrydowego jest na porównywalnym poziomie cenowym z pojazdem spalinowym, a czynności obsługowe w samochodach elektrycznych są niemal identyczne jak w samochodach spalinowych. Silnik elektryczny zwykle jest bezawaryjny, obsługi wymaga jedynie akumulator trakcyjny i układ chłodzenia sytemu przetwarzania mocy. Samochód hybrydowy jest wyposażony w dwa systemy chłodzenia i jest to zasadnicza różnica w konstrukcji hybrydy w stosunku do tradycyjnego pojazdu, wpływająca na zakres obsługi serwisowej. W pojazdach hybrydowych jest mniej elementów zużywających się w czasie eksploatacji, a więc wymagających wymiany, np. pasek klinowy lub zębaty, sprzęgło cierne, rozrusznik czy alternator. Zastosowanie systemu rekuperacji energii dwu lub nawet trzykrotnie spowalnia zużywanie się tarcz i klocków hamulcowych. Większą trwałość wykazują opony samochodowe i elementy układu wydechowego. Usterki systemu hybrydowego występują sporadycznie. Mogą one być związane z uszkodzeniem instalacji elektrycznej, niesprawnością baterii trakcyjnej, silnika/prądnicy lub inwertera (sterownia i przetwornicy).

Najmniej czynności (i co za tym idzie - najmniej pieniędzy) wymaga serwisowanie samochodu wyłącznie elektrycznego, który z powodu braku silnika spalinowego, sprzęgła i skrzyni biegów nie wymaga wymiany olejów, świec, filtrów paliwa, powietrza, pasków i skomplikowanych elementów osprzętu. Do obsługi i naprawy pozostają tylko układ kierowniczy, hamulcowy, zawieszenie i układ jezdny oraz mało awaryjne systemy elektryczne (szerzej w: Hutyra, 2017: 34-35).

Podstawowym wyzwaniem dla warsztatów samochodowych, a przede wszystkim mechaników - jest konieczność stałego zdobywania wiedzy i jej pozyskiwania niekiedy z różnych źródeł oraz umiejętność korzystania z rosnącej liczby informacji. Różnorodność marek, typów i rodzajów samochodów wymusza na warsztatach konieczność dostępu do katalogów technicznych części, procedur serwisowania, czasów napraw i obsługi, a ciągłe doskonalenie swoich umiejętności i poszerzanie zasobu wiedzy to od dawna nieodzowny element pracy każdego mechanika samochodowego. Stale rosną ranga i zapotrzebowanie na specjalistyczne szkolenia i pozyskiwanie wiedzy w zakresie nowych rozwiązań technicznych w samochodach. Poszerza się też zakres udokumentowanych specjalizacji osób pracujących w serwisach samochodowych, w tym i samych warsztatów. Oprócz już tradycyjnych specjalizacji mechanicznych, blacharskich, lakierniczych, oponiarskich, elektromechanicznych, mechatronicznych czy też diagnostyki powstają specjalizacje związane z rodzajem stosowanych paliw, rozwiązaniami IT, naprawą elementów z tworzyw 
sztucznych, kompozytów, autodetailingiem czy napędami elektrycznymi, a w przyszłości - z pojazdami autonomicznymi. Przykładowo mechanik zajmujący się obsługą pojazdu hybrydowego lub elektrycznego musi mieć stosowne uprawnienia SEP.

Sytuacja związana $z$ wiedzą i informacją dotyczy także innych branż. W ubiegłym wieku wiedza na świecie podwajała się co 10 lat i była ponad tysiąc razy większa niż na początku minionego stulecia (Sztumski, 2008), natomiast liczba informacji wzrasta przeszło dwukrotnie co dwa lata (Co dwa lata..., 2011).

Kolejnym ważnym elementem jest stałe uzupełnianie i aktualizowanie przez warsztaty nowoczesnego sprzętu serwisowego, urządzeń diagnostycznych czy testerów pozwalających nie tylko zdiagnozować usterkę, lecz także w ogóle rozpocząć proces obsługi i naprawy samochodu. Pojazdy samochodowe stają się w coraz większym stopniu uzależnione od systemów elektronicznych. Trudno zatem oczekiwać, aby można je było naprawiać wyłącznie z użyciem tradycyjnych narzędzi.

Digitalizacja ma przede wszystkim na celu usprawnienie eksploatacji maszyny. Maszyny i urządzenia coraz częściej potrafią się ze sobą sprawnie komunikować i podobnych powszechnych rozwiązań w niedalekiej przyszłości należy spodziewać się w branży motoryzacyjnej. Wszystko to nie oznacza wyeliminowania pracy mechanika samochodowego. Wprost przeciwnie - następuje wzrost rangi tego zawodu i rosną wymagania związane z wykształceniem mechaników oraz kwalifikacjami zawodowymi. W przyszłości bardzo prawdopodobny stanie się nierozłączny układ mechanik-urządzenie skanująco-diagnostyczne (Warsztat przyszłości, 2016). Mechanik bez urządzenia diagnostycznego nie będzie mógł rozpocząć procesu naprawy, jednak urządzenie to nadal będzie wymagało obsługi ze strony człowieka.

Obecnie w większości przypadków klient udziela mechanikowi informacji na temat pojazdu oraz ewentualnych nieprawidłowości związanych z jego eksploatacją. Uzupełnieniem tych działań w przyszłości stanie się prewencyjna diagnostyka pojazdów, w której dane i informacje $\mathrm{z}$ chmur, zbierane podczas regularnych jazd, będą wykorzystywane do analizy stanu najważniejszych zespołów i elementów samochodu. Jeśli dane będą wskazywać na objawy zużycia elementów, to kierowca zostanie powiadomiony o tym przed wystąpieniem usterki i otrzyma polecenie udania się do warsztatu (Łukaszewicz, Giecewicz, 2017). W perspektywie najbliższych kilku lat przepływ danych pomiędzy różnymi systemami i ich integracja zwiększą się wielokrotnie, a tego typu informacje przekazywane będą automatycznie, bezprzewodowo i stale (Warsztat przyszłości, 2016). Znaczącej zmianie ulegnie też funkcjonowanie tzw. automatycznego, inteligentnego doradcy, analizującego zachowania kierowcy na drodze i na tej podstawie podpowiadającego najkorzystniejsze rozwiązania przy wyborze opon, części zamiennych i innych materiałów eksploatacyjnych (Mroczkowski, 2014).

Oprócz systemu napraw w istotny sposób zmieni się także proces obsługi klienta. Podstawę tutaj stanowić będzie Internet, a konsultanci zostaną zastąpieni aplikacjami, dzięki którym klient złoży zlecenie wykonania danej usługi, umówi się na dogodny termin wizyty w warsztacie oraz otrzyma i zapłaci przez Internet rachunek za usługę. Przewiduje się, że informatyzacja pójdzie nawet o krok dalej tak, że dalsza komunikacja z klientem prowadzona będzie wyłącznie za pośrednictwem nowoczesnych narzędzi (Wizyta u mechanika, 2016).

Można wyobrazić sobie sytuację w przyszłości, kiedy mechanik na tablecie zaznaczy, że wymiany wymagają np. klocki hamulcowe, tarcze lub inne elementy, o których nie było 
mowy w zleceniu serwisowym. Klient tę informację odczyta na swoim urządzeniu mobilnym, po czym podejmie decyzję o wykonaniu usługi. Zamówienie klienta może być realizowane automatycznie, gdyż potrzebne podzespoły zostaną przyporządkowane do konkretnego pojazdu według katalogu części. Rola człowieka w takim wypadku zostanie więc zminimalizowana - dotychczasowa komunikacja z klientem odbywa się przeważnie przez telefon, a zlecenie na części do wymiany składa mechanik (Wizyta u mechanika, 2016).

W warsztatach nastąpi także ograniczenie dokumentów w formie papierowej. Wynikać to będzie ze stale rosnącej świadomości ekologicznej oraz sugestii ze strony administracji państwowej lub samych klientów. Zwiększy się również poziom wykorzystania w naprawach części i materiałów pochodzących z recyklingu (szerzej: Janczewski, 2012: 131-142).

Niewykluczone, że kluczem dla rozwoju i sukcesu w branży serwisów samochodowych będzie konsolidacja i szeroko rozumiana współpraca, $\mathrm{np}$. w formie powiązań sieciowych (szerzej: Włodarczyk, Janczewski, 2011; 2010), a także kompleksowa oferta usług. Stąd największą popularnością cieszyć się będą warsztaty świadczące usługi kompleksowe, gdzie np. oprócz samej naprawy wykona się badania techniczne, wymieni opony, umyje samochód. Równocześnie wzrośnie zapotrzebowanie na usługi zarządzania flotą, usługi assistance i samochody zastępcze, a także na usługi warsztatów mobilnych. W niedalekiej przyszłości każdy liczący się warsztat samochodowy powinien dysponować flotą samochodów zastępczych dla swoich klientów.

\section{Podsumowanie}

Konieczność dbania o środowisko naturalne i tym samym coraz bardziej restrykcyjne normy emisji spalin powodują, że zastępowanie napędów spalinowych napędami elektrycznymi jest nieuniknione. Tradycyjne silniki jeszcze przez kilka dekad mogą być jednak nieodzowne w pojazdach używanych do dalekobieżnego transportu towarów (transport morski, kolejowy, a nawet drogowy), natomiast w transporcie indywidualnym szerokie zastąpienie silników spalinowych przez silniki elektryczne to perspektywa zaledwie kilkunastu lat.

Samochód nadal będzie stanowił główny środek zarówno transportu indywidualnego, jak i zbiorowego. Brakuje przesłanek wskazujących na to, że w najbliższej przyszłości może być wyeliminowany z użycia i zastąpiony przez inne środki, a jego eksploatacja będzie nadal wymagała udziału zaplecza usługowego tak jak w wypadku każdej innej maszyny.

Do kluczowych czynników wynikających z perspektywy nieuchronnej elektromobilności i upowszechniania się internetu rzeczy, które istotnie wpłyną na sektor warsztatów samochodowych, można m.in. zaliczyć: pozyskiwanie nowej wiedzy i umiejętność korzystania z rosnącej liczby informacji, uzupełnianie i stałe aktualizowanie nowoczesnego sprzętu serwisowego, zmiany w procesach obsługi i naprawy pojazdów oraz uproszczenie i ograniczenie ich czynności, diagnozowanie samochodów i aktualizowanie ich oprogramowania na odległość. Istotne także będą zmiany w procesach obsługi klienta, wzrost świadomości ekologicznej użytkowników, praktykowanie strategii zapobiegania awarii, serwisowanie u klienta, konsolidacja i szeroko rozumiana współpraca z innymi warsztatami, kompleksowa oferta serwisowa oraz całodobowa gotowość warsztatów do świadczenia usługi. 
Literatura

Refernces

Audi systematycznie rozbudowuje swoja strategię e-paliw. (2017, 12 sierpnia). Pozyskano z: http://pim.pl/ audi-systematycznie-rozbudowuje-swoja-strategie-e-paliw/

Baterie gra fenowe. (2016; 10 lipca 2017). Pozyskano z: http://www.bateriegrafenowe.pl/

Benysek, G. (2017). Bezemisyjny transport publiczny - założenia merytoryczne. W: A. Nawrat, Nowe podejście NCBR do finansowania programów badawczych. Pozyskano z: http://www.nauka.gov.pl/ g2/oryginal/2017_01/74e74a90d4088713fbd19b56b962ffaa.pdf

Branża motoryzacyjna Raport 2015. (2018, 14 września). Pozyskano z: http://www.pzpm.org.pl/Rynekmotoryzacyjny/Roczniki-i-raporty/Raport-branzy-motoryzacyjnej-2015.

Brzeziński, K. (2017, 10 września). Idzie rewolucja! Silniki benzynowe przestana emitować $\mathrm{CO}_{2}$ !. Pozyskano z: https://www.autofakty.pl/aktualnosci/paliwo-syntetyczne-bosch/

Co dwa lata ilość danych na świecie wzrasta przeszło dwukrotnie - nowe zadania i możliwości informatyki zwiąane ze zjawiskiem Big Data. (2011; 10 września 2017). Pozyskano z: https://poland.emc.com/ about/news/press/2011/20110628-01.htm

Connected Car Effect 2025. (2017, 15 lipca). Pozyskano z: http://www.bosch-presse.de/pressportal/de/ en/bosch-study-shows-more-safety-more-efficiency-more-free-time-with-connected-mobility-82818.html

Dach solarny i Powerwall 2 Tesli. (2016; 10 września 2017). Pozyskano z: http://www.green-projects. $\mathrm{pl} / 2016 / 11 /$ dach-solarny-powerwall-2-tesla/

Emilewicz, J. (2017). Szansa na rozwój. Fleet - Napędy Alternatywne. Wydanie specjalne. Warszawa: PZPM.

Główny Urząd Statystyczny. (2017). Transport - wyniki działalności w 2016 roku. Warszawa.

Greenough, J. (2015; 2017, 12 października). This is how big connected cars will be in regions around the world. Pozyskano z: http://www.businessinsider.com/how-big-connected-cars-will-be-in-regionsaround-the-world-2015-3? IR=T:

Hrymniak, W. (2017). Elektromobilność. Program flagowy E-bus. Polski Fundusz Rozwoju SA. Pozyskano z: https://www.mr.gov.pl/media/35679/2Ebus.pdf

Hutyra, M. (2017). Nie taki diabeł straszny. Fleet - Napędy Alternatywne. Wydanie specjalne. Warszawa: PZPM, 34-35.

Janczewski, J. (2012). Wybrane problemy logistyki zwrotnej w branży usług motoryzacyjnych. ZIwGiB 1(14), AHE w Łodzi, 131-142.

Januszkiewicz, A. (2017a, 30 września). Bosch: aktualizacja oprogramowania auta dzięki chmurze. Pozyskano z:http://motofaktor.pl/m/50,2/AKTUALNOSCI/Bosch-aktualizacja-oprogramowaniaauta-dzieki-chmurze, $7592 . \mathrm{html}$

Januszkiewicz, A. (2017b; 30 września). Bosch: Internet rzeczy w motoryzacji na Mobile World Congress 2017. Pozyskano z: http://motofaktor.pl/m/50,2/AKTUALNOSCI/Bosch-Internet-rzeczy-wmotoryzacji-na-Mobile-World-Congress-2017,6608.html

Kościelniak, P. (2011; 2017, 29 września). Naukowcy próbują produkować tanie sztuczne paliwo. Pozyskano z: http://www.rp.pl/artykul/637505-Nukowcy-probuja-produkowac-tanie-sztuczne-paliwo.html

Kulik, W. (2015; 2017, 30 sierpnia). Tesla: auta elektryczne z zasiegiem $1200 \mathrm{~km} w 2020$ roku. Pozyskano z: http://www.benchmark.pl/aktualnosci/tesla-auta-elektryczne-z-zasiegiem-1200-km-w-2020roku.html

Łukaszewicz, P., Giecewicz, M. (2017). Bezpieczny transport - wizja motoryzacji wg Boscha na targach IAA. Nowoczesny warsztat, 10(217), 5.

Maj, M. (2013; 2017, 18 lipca). Samochód $z$ wypożyczana bateriq i DRM - Renault sprzedaje coś takiego. Pozyskano z: http://di.com.pl/samochod-z-wypozyczana-bateria-i-drm-renault-sprzedaje-cos-takiego- 49104 
Ministerstwo Energii. (2017). Plan rozwoju elektromobilności w Polsce. Energia dla przyszłości. Warszawa.

Mirai. Nowa era w motoryzacji (2016; 2017, 30 września). Pozyskano z: https://www.toyota.pl/new-cars/ mirai/index.json

Mroczkowski, J. (2014; 2017, 10 maja). Jak w przyszłości będzie wyglądał serwis samochodowy?. Newseria. Pozyskano z: http://www.biznes.newseria.pl/komunikaty/motoryzacja/jak_w_przyszlosci,b352126076)

Nawrat, A. (2017). Nowe podejście NCBR do finansowania programów badawczych - założenia do programu na rzecz bezemisyjnego transportu publicznego. Pozyskano z: http://www.nauka.gov.pl/g2/ oryginal/2017_01/74e74a90d4088713fbd19b56b962ffaa.pdf

Owczarzak, W. (2015). Pojazdy autonomiczne na przykładzie samojeżdżącego samochodu Google`a. Logistyka, 3, 3680-3684. Pozyskano z: http://www.czasopismologistyka.pl/artykuly-naukowe/ send/333-artykuly-na-plycie-cd-1/7946-owczarzak-pojazdy-autonomiczne+

Piszcz, J. (2017, 15 lipca). Bosch: rozwiązania przyszłości na targach IAA. Pozyskano z: http://motofaktor.

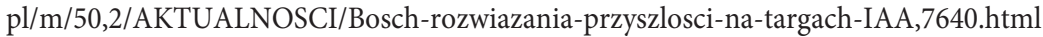

POWERFUL Report Summary. (2015; 2017, 29 września). Pozyskano z: http://cordis.europa.eu/result/ rcn/163424_en.html

Program priorytetowy System zielonych inwestycji - GEPARD - Bezemisyjny transport publiczny. (2017, 29 września). Pozyskano z file:///C:/Users/Jerzy/Downloads/program_gepard_bezemisyjny_transport_publiczny.pdf

Raport: Rewolucja na drogach, czyli elektromobilność i carsharing. (2017, 15 sierpnia). BiznesAlert. http://biznesalert.pl/raport-rewolucja-drogach-czyli-elektromobilnosc-carsharing/

Strategia na rzecz Odpowiedzialnego Rozwoju z akceptacja rządu. (2017, 27 września). https://www. $\mathrm{mr}$.gov.pl/strony/aktualnosci/strategia-na-rzecz-odpowiedzialnego-rozwoju-z-akceptacja-rzadu/

Szokujący raport. Samochody elektryczne nie sq ekologiczne. (2017, 27 września). http://motoryzacja.interia.pl/wiadomosci/producenci/news-szokujacy-raport-samochody-elektryczne-nie-sa-ekologiczne,nId, 2411032

Sztumski, W. (2008; 2015, 10 września). Paradoksalne społeczeństwo wiedzy. Sprawy Nauki, 11-12. Pozyskano z: http://www.sprawynauki.edu.pl/index.php?option=com_content\&task= view\&id=895 \& Itemid $=35$

Śnigurski, P. (2017). Downsizing, czyli pojemne pojęcie. Fleet - Napędy Alternatywne. Wydanie specjalne, Warszawa: PZPM.

Ta decyzja zmieni przyszłość producentów części. (2017, 27 września). Pozyskano z: https://motofocus.pl/informacje/nowosci/56838/ta-decyzja-zmieni-przyszlosc-producentow-czesci?utm_ source=newsletter48\&utm_medium $=$ email\&utm_campaign $=$ newsletter\&utm_content $=$ cala-branza-razem-w-jednym-miejscu

Unia o inteligentnych samochodach. (2016, 2017, 2 września). https://www.l-instruktor.pl/aktualnosci/ unia-o-inteligentnych-samochodach.html\#.WgiKMlvWzIU

Warsztat przyszłości. (2016; 2017, 17 września). ProfiAutoPL. https://www.youtube.com/watch?v=vjpzHCfbAPM

Wizyta u mechanika. Jak będzie wyglądać w przyszłości?. (2016; 27 września). http://www.motofakty.pl/ artykul/wizyta-u-mechanika-jak-bedzie-wygladac-w-przyszlosci.html

W listopadzie ruszy konkurs na prototyp polskiego samochodu elektrycznego. (2017, 7 września). Pozyskano z: http://pim.pl/w-listopadzie-ruszy-konkurs-na-prototyp-polskiego-samochodu-elektrycznego-na-swiatowym-rynku-jest-nisza-dla-krajowych-producentow/

Włodarczyk, M., Janczewski, J. (2010). Przedsiębiorczość w organizacjach sieciowych w sektorze napraw samochodów. Przedsiębiorczość - Edukacja, 6, 157-169.

Włodarczyk, M., Janczewski, J. (2011). Warsztaty samochodowe w warunkach globalizacji. Przedsiębiorczość - Edukacja, 7, 159-172.

Zaręba, P. (2017). Program elektromobilności - główne założenia. Ministerstwo Energii. Pozyskano z: https://www.mr.gov.pl/media/35678/1Ecar.pdf 
Jerzy Janczewski, inżynier mechanik, doktor nauk ekonomicznych w zakresie zarządzania, adiunkt w Katedrze Systemów Transportowych Akademii Humanistyczno-Ekonomicznej w Łodzi. Zainteresowania badawcze autora koncentrują się na logistyce zwrotnej i problematyce zarządzania przedsiębiorstwami mikro i małymi z branży usług motoryzacyjnych oraz transportu drogowego.

Jerzy Janczewski, mechanical engineer, doctor of economic sciences in management. His research interests focus on reverse logistics and management issues of micro- and small enterprises in the industry of automotive service and road transport.

\section{Adres/Address:}

Akademia Humanistyczno-Ekonomiczna

Katedra Systemów Transportowych

ul. Rewolucji $1905 \mathrm{nr} 64$

90-222 Łódź, Polska

e-mail: jerzyjanczewski@poczta.onet.pl 